\title{
Influence of a Debris Layer on the Melting of Ice on Lirung Glacier, Langtang Valley, Rasuwa, Nepal
}

\author{
Sonika Shahi ${ }^{1}$, Rijan B. Kayastha ${ }^{1}$, Prashant Baral ${ }^{1}$, Pradeep K. Mool ${ }^{2}$ \\ 1 Department of Environmental Science and Engineering, School of Science, Kathmandu University, \\ Nepal. \\ 2 Integrated Water and Hazard Management, International Centre for Integrated Mountain \\ Development (ICIMOD), Kathmandu, Nepal
}

\begin{abstract}
This paper provides information about the variation of ice ablation rate underneath the highly heterogeneous debris layer on Lirung Glacier in Langtang Valley, Rasuwa district, Nepal. Ice melt under a debris cover has been commonly modelled using two approaches: physically-based energy-balance models and more empirical temperature-index models. Energy Balance Model (EMB) was used at the point scale to calculate melt under a debris-covered glacier. Because of the high heterogeneity of the surface layer, the ablation rate varies throughout the glacier. The average value of thermal resistance $(R)$ in association with the meteorological variables is found to be sufficient enough to give the consistent value of ablation of glacier ice underneath the debris layer. Solar radiation is the only dominant heat flux which contributes to melting of ice under the debris cover with a little contribution of sensible heat flux in dawn because of the heat storage phenomenon of the debris. In spite of several simplifications, the model performs well and modelled melt rates give a good match to observed melt rates. Thus for accurate distributed melt modelling at different locations of the debris covered glacier it is important to considered the effects of both the external variables and the physical properties of the debris material, which in turn gives estimates of the amount of discharge from the glacier, an important component of the local water resources.
\end{abstract}

Keywords: Debris cover, Himalayan glacier, Lirung Glacier, ice melt, Energy flux

\section{INTRODUCTION}

The expansion of insulating debris mantles across glacier ablation zones feeds back negatively on melt rates (Mihalcea et al., 2006). This is important for forecasting the glacier response to climate change on a decadal scale and its impacts on the runoff of mountain regions (Bozhinskiy et al., 1986). Debris-covered glaciers are common in alpine environments such as the Himalaya, the Peruvian Andes and the Southern Alps of New Zealand (Benn et al., 2004). Glacier termini are commonly characterized by the presence of large quantities of debris, existing

* Corresponding author : Sonika Shahi, E-mail: shahisonica@gmail.com 
both within and on top of the glacier ice. The surface debris cover largely controls the rates of ice melt which, in turn, affects the mode of formation of glacially deposited landforms (Nakawo and Young, 1981). Quantitative assessment of ablation rate under a debris layer can also be significant for studies of glacier mass balance (Inoue, 1977), glacier dynamics (Glazyrin, 1975; Nakawo, 1979), and glacial history (Bondarev, 1961; Kite and Reid, 1977; Whalley, 1979).

With the current warming climate, the number of debris-covered glaciers and also the magnitude of debris cover on single glaciers seem to be increasing in most of the world's mountain regions. The ablation rate under the debris layer is a function of external variables including radiation and air temperature, as well as physical characteristics of the layer such as thickness, albedo, and thermal conductivity. The effect of the debris layer on ablation of glacier ice should be studied in association with these variables. Observations have been made to evaluate the effect of a debris layer on melting of glacier ice, snow, and lake ice (Østrem, 1959; Wijngaarden, 1961; Loomis, 1970; Moribayashi and Higuchi, 1972; Fujii, 1977; Adhikary et al., 1997, 2000). Few studies, however, have considered the effects of both the external variables and the physical properties of the debris material (Reid and Brock, 2010; Mihalcea et al., 2006; Nicholson and Benn, 2006). Determination of the debris thermal properties, temperature and humidity values needed for modelling melt beneath debris covers is problematic, while little is known about the impact of variation in atmospheric stability, and the role of evaporation and condensation in the debris surface energy balance (Nicholson and Benn,
2006; Brock et al., 2007). Empirical degreeday approaches are normally used (Rana et al., 1995; Kayastha et al., 2000; Mihalcea et al., 2006; Singh et al., 2006; Hagg et al., 2008) owing to limited data availability in remote mountain locations and poor knowledge of key processes. Accurate melt modelling at different locations of the debris covered glacier is important to understand the effect of a highly variable debris layer on melt and thus improve the distributed modelling, which in turn gives estimates of the amount of discharge from the glacier, an important component of the local water resources. As the melting process in this area is complex, usually the melting component is not included in the river runoff process. This suggests that the evaluation of ice melt under debris cover is important for runoff modeling of glacierised drainage basins (Rana et al., 1995). Nakawo and Young (1982) have shown that glacier melt under debris layer can be estimated from surface temperature and meteorological variables. Heat budget considerations with a debris layer on top of glacier ice suggested that 'thermal resistance' of the debris layer could be estimated from surface temperature and the heat fluxes at the debris surface, and the ablation rate of the underlying glacier ice from the thermal resistance and meteorological data (Nakawo and Rana, 1999).

The aim of this paper is to report observed melt rates of glacier ice under varying debris thickness, and comparison of the observed results with the calculated results from physically based energy balance model. In this study, we concentrated on the melt regime of the ablation area because this is the zone of the glacier that is most contributing to glacier runoff. 


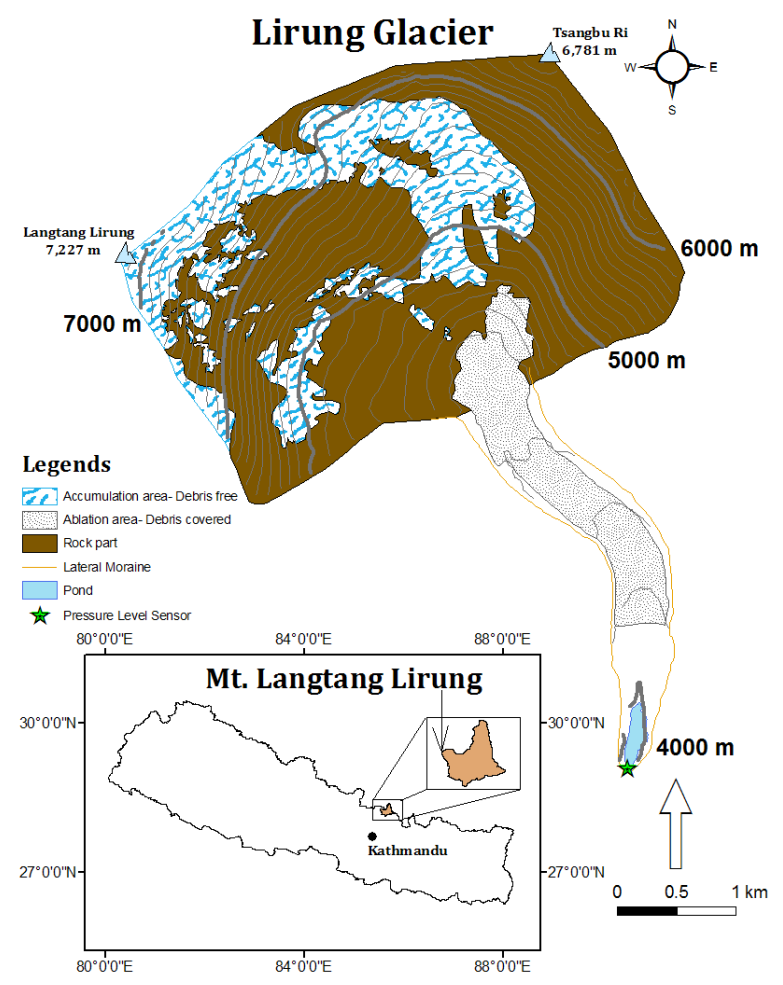

Figure 1: Topographic map of Lirung Glacier drawn from rapid eye satellite image, 2010.

\section{THE STUDY SITE}

This study is carried out on Lirung Glacier $\left(28^{\circ} 15^{\prime} \mathrm{N}, 85^{\circ} 32^{\prime} \mathrm{E}\right)$ (Figure 1) which lies in Langtang National Park in Rasuwa district with the total area of $1710 \mathrm{~km} 2$. The elevation ranges from the terminus at $4000 \mathrm{~m}$ a.s.1. to Mt. Langtang Lirung peak at $7234 \mathrm{~m}$ a.s.1. and is located northwest of the last permanently inhabitated village of Kyangjing (3857 m a.s.1.). In the Langtang Valley, there are 18 debriscovered glaciers such as the Lirung Glacier and 59 clean-type glaciers such as the Yala Glacier (Asahi, 1998). The Langtang catchment area is $353.89 \mathrm{~km} 2$. The Lirung Glacier is the fourth largest debris covered glacier in this catchment with the area covering about $13.35 \mathrm{~km} 2$ of which $3.30 \mathrm{~km} 2$ is accumulation area, $1.42 \mathrm{~km} 2$ is ablation area and $7.42 \mathrm{~km} 2$ is rock part. It consists of a very steep accumulation area, ab- lation area covered with thick mantle of debris $(>50 \mathrm{~cm})$ which is detached with the accumulation area, followed by a proglacial valley with several small ponds and one large proglacial pond which is disconnected from the glacier terminus. From this pond the melt water flows out into a steep stream downwards, entering the Langtang River down in the valley.

\section{MATERIALS AND METHOD}

\subsection{Field Measurement}

A glacio-meteorological experiment was carried out from May to October 2012, spanning three seasonal period i.e. Period I ( $7^{\text {th }}$ May $-16^{\text {th }}$ June, 2012), Period II (1 $7^{\text {th }}$ June $-19^{\text {th }}$ September, 2012) and Period III $\left(20^{\text {th }}\right.$ September $-25^{\text {th }}$ October, 2012) for which some instruments were set up. The setup consisted of one Automatic Weather Station (AWS); 9 ablation stakes along the glacier in correspondence to different debris thicknesses ranging from $6-40 \mathrm{~cm}$, a thermistor chain to measure the temperature profile of a debris layer; 3 tiny-tags to measure temperature on the top and bottom of the debris layer for different debris thicknesses and 14 temperature sensors to measure air temperature at $2 \mathrm{~m}$ above the debris layer, 7 of them with an additional sensor on the surface.

\subsubsection{Meteorological data}

Meteorological measurements were carried out using AWS which is centrally located (i.e. $28.23489^{\circ} \mathrm{N}$ and $85.561361^{\circ} \mathrm{E}$ ) on the debris covered ablation zone of Lirung Glacier at 4195 $\mathrm{m}$ a.s.1 (Figure 2). The debris thickness on that location could not be determined as it exceeded $1 \mathrm{~m}$. The AWS measured 5 minutes records of the following meteorological and surface variables: air temperature $\left({ }^{\circ} \mathrm{C}\right)$ above $2 \mathrm{~m}$, relative humidity $(\%)$, wind speed $\left(\mathrm{ms}^{-1}\right)$, wind direction $\left(^{\circ}\right)$, incoming and outgoing shortwave 


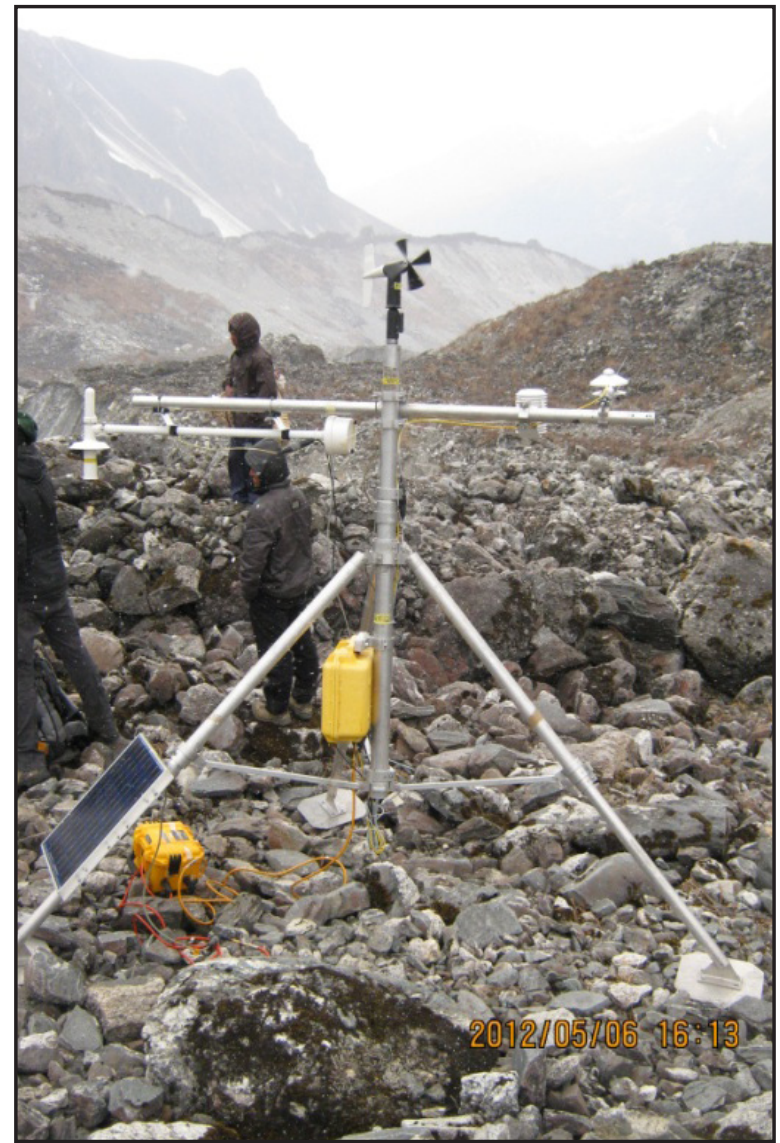

Figure 2: Automatic Weather Station installed on debris covered Lirung Glacier at 4195 m a.s.I.

radiation $\left(\mathrm{Wm}^{-2}\right)$ and surface temperature $\left({ }^{\circ} \mathrm{C}\right)$ for the whole measurement period. Data were measured every 5 second and every 5 minute averages stored on respective sensors. All measurements were taken at a height of $2 \mathrm{~m}$. The AWS is therefore representative of the surface and meteorological conditions of the glacier ablation area at that point. All meteorological data were averaged into hourly means and used as input to the melt models. There are some data gaps on 12 May, 2012 due to the malfunctioning of the AWS.

\subsubsection{Ablation data (Lowering)}

Ablation data were obtained using bamboo ablation stakes. In total 9 ablation stakes along the glacier (Figure 3) in correspondence to differ-

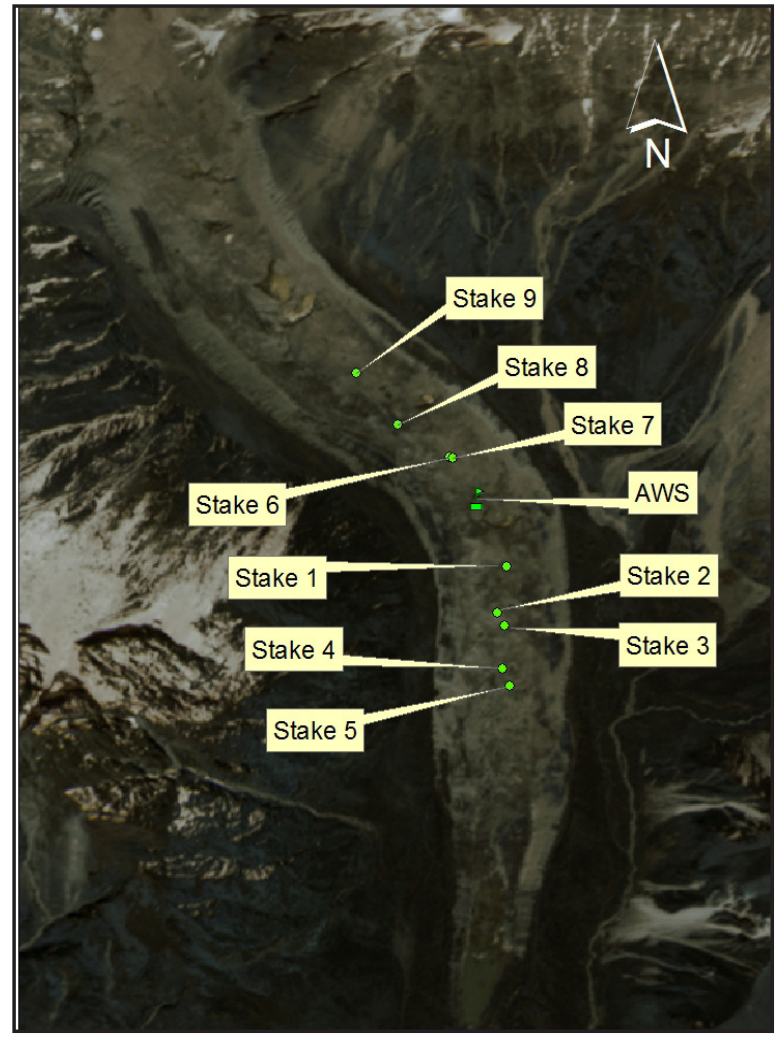

Figure 3: Satellite image (Rapid eye, 2010) showing position of stakes and AWS along the ablation zone of Lirung Glacier.

ent debris thicknesses ranging from $6-40 \mathrm{~cm}$ were installed in order to analyze the influence of debris on melt for different thicknesses. Direct measurements of surface lowering at the ablation stakes were done during May (installation period), late June, early September and late October.

\subsection{Energy balance calculation}

The energy balance equation on top of a debris layer can be expressed as:

$$
\mathrm{Q}_{\mathrm{C}}=\mathrm{Q}_{\mathrm{R}}+\mathrm{Q}_{\mathrm{H}}+\mathrm{Q}_{\mathrm{E}}+\mathrm{Q}_{\mathrm{P}}
$$

where $Q_{C}, Q_{R}, Q_{H}, Q_{E}$ and $Q_{P}$ are conductive heat flux through the debris, net radiation flux, sensible heat flux, latent heat flux and heat contributed by precipitation. The net radiation flux is the sum of net shortwave $\left(\mathrm{S}_{\text {net }}\right)$ and longwave radiation $\left(\mathrm{L}_{\text {net }}\right)$ fluxes. 


\subsubsection{Solar shortwave radiation}

The net shortwave radiation is computed as the difference between incoming $(\mathrm{S} \downarrow)$ and reflected $(S \uparrow)$ solar shortwave radiation data at the debris surface.

$$
\mathrm{S}_{\text {net }}=\mathrm{S} \downarrow-\mathrm{S} \uparrow
$$

Alternatively, if data for the debris albedo is available then we can use

$$
\mathrm{S}_{\text {net }}=\mathrm{S} \downarrow\left(1-\alpha_{\mathrm{d}}\right)
$$

where $\alpha_{d}$ is the debris albedo.

\subsubsection{Longwave radiation}

Dilley and O'Brian (1998) and Unsworth and Monteith (1975) present equations to calculate and parameterize the incoming longwave radiation.

$$
\mathrm{L} \downarrow=\varepsilon_{\mathrm{a}} \sigma \mathrm{T}_{\mathrm{a}}^{4}
$$

where $\varepsilon_{\mathrm{a}}$ is the apparent emissivity of the sky (Unsworth and Monteith, 1975) $\sigma$ is the StefanBoltzmann constant $\left(5.67 \times 10^{-8} \mathrm{~W} \mathrm{~m}^{-1} \mathrm{~K}^{-4}\right)$, and $\mathrm{T}_{\mathrm{a}}$ is the air temperature in Kelvin near the surface (typically $2 \mathrm{~m}$ ).

Outgoing longwave radiation is calculated from the Stefan-Boltzmann law:

$$
\mathrm{L} \uparrow=-\varepsilon_{\mathrm{d}} \sigma \mathrm{T}_{\mathrm{s}}^{4}
$$

where $\varepsilon_{\mathrm{d}}$ is the debris surface emissivity, $\mathrm{T}_{\mathrm{s}}$ is the surface temperature in Kelvin and $\sigma$ is the StefanBoltzmann constant $\left(5.67 \times 10^{-8} \mathrm{~W} \mathrm{~m}^{-1} \mathrm{~K}^{-4}\right)$.

The net longwave radiation $\left(\mathrm{L}_{\text {net }}\right)$ is calculates as the difference between incoming and outgoing longwave radiation.

$$
\mathrm{L}_{\text {net }}=\mathrm{L} \downarrow-\mathrm{L} \uparrow
$$

\subsubsection{Turbulent heat fluxes}

The convective or turbulent heat fluxes $\mathrm{Q}_{\mathrm{H}}$ and $\mathrm{Q}_{\mathrm{E}}$ are estimated using the bulk aerodynamic method:

$$
\begin{aligned}
& \mathrm{Q}_{\mathrm{H}}=\beta \mathrm{u}\left(\mathrm{T}_{\mathrm{a}}-\mathrm{T}_{\mathrm{s}}\right) \\
& \mathrm{Q}_{\mathrm{E}}=\beta \mathrm{u} \mathrm{L}_{\mathrm{e}} \frac{0.622}{\mathrm{Pc}_{\mathrm{P}}}\left(\mathrm{e}_{\mathrm{a}}-\mathrm{e}_{\mathrm{s}}\right)
\end{aligned}
$$

Where $\beta$ is the bulk transfer coefficient (4.9 J $\mathrm{m}^{-3} \mathrm{~K}^{-1}$, Naruse et al., 1970); $\mathrm{u}$ is wind speed $\left(\mathrm{m} \mathrm{s}^{-1}\right) ; \mathrm{L}_{\mathrm{e}}$ is the latent heat of evaporation (2.5 $\left.\times 10^{6} \mathrm{~J} \mathrm{~kg}^{-1}\right) ; \mathrm{P}$ is atmospheric pressure $(\mathrm{hPa})$; $\mathrm{c}_{\mathrm{P}}$ is the specific heat of air at constant pressure $\left(1005 \mathrm{~J} \mathrm{~kg}^{-1}{ }^{\circ} \mathrm{C}^{-1}\right)$; $\mathrm{e}_{\mathrm{a}}$ is vapour pressure of the air $(\mathrm{hPa}) ; \mathrm{e}_{\mathrm{s}}$ is saturation vapour pressure at the surface $(\mathrm{hPa})$.

\subsubsection{Heat flux due to precipitation}

The heat flux due to precipitation $\left(Q_{\mathrm{p}}\right)$ is often ignored in glacier studies because it tends to be extremely small, but in this study it is taken under consideration to see its effect on melting of glacier especially during monsoon period. The heat flux due to precipitation is calculated in a similar manner to Hay and Fitzharris (1988).

$$
\mathrm{Q}_{\mathrm{P}}=\rho_{\mathrm{w}} \mathrm{c}_{\mathrm{w}} \mathrm{w}\left(\mathrm{T}_{\mathrm{r}}-\mathrm{T}_{\mathrm{s}}\right)
$$

where $\rho_{\mathrm{w}}$ is the density of water $\left(999.7 \mathrm{~kg} \mathrm{~m}^{-3}\right)$, $\mathrm{c}_{\mathrm{w}}$ is the specific heat capacity of water $(4181.3$ $\mathrm{J} \mathrm{kg}^{-1} \mathrm{~K}^{-1}$ ), w is the rainfall rate in $\mathrm{ms}^{-1}$ and $\mathrm{T}_{\mathrm{r}}$ is the rain temperature, which in the absence of complete information is set equal to the measured air temperature, Ta (e.g. Reid and Brock, 2010). Our study considers only the effect of precipitation heat flux at the top of the debris layer, where the surface energy balance is defined hence neglecting the phenomenon like evaporation and percolation of rain through the debris layer.

A linear variation of temperature is assumed in the debris layer (Kayastha et al., 2000),

$$
\mathrm{Q}_{\mathrm{C}}=\frac{\mathrm{T}_{\mathrm{s}}}{\mathrm{R}}
$$

Where $\mathrm{Ts}$ is the debris surface temperature relative to melting $\left(0^{\circ} \mathrm{C}\right)$ and $\mathrm{R}\left(\mathrm{m}^{2}{ }^{\circ} \mathrm{C} \mathrm{W}^{-1}\right)$ is the effective thermal resistance of the debris layer. 
The heat used for ice ablation Qc is calculated as,

$$
\mathrm{Q}_{\mathrm{c}}=\mathrm{L}_{\mathrm{f}} \rho_{\mathrm{i}} \mathrm{r}
$$

Where Lf is the latent heat of ice $\left(334 \times 10^{3} \mathrm{~J}\right.$ $\left.\mathrm{kg}^{-1}\right), \rho_{\mathrm{i}}$ is density of the ice $\left(900 \mathrm{~kg} \mathrm{~m}^{-3}\right)$ and $\mathrm{r}$ is ablation rate of ice in specific debris thickness $\left(\mathrm{m} \mathrm{s}^{-1}\right)$.
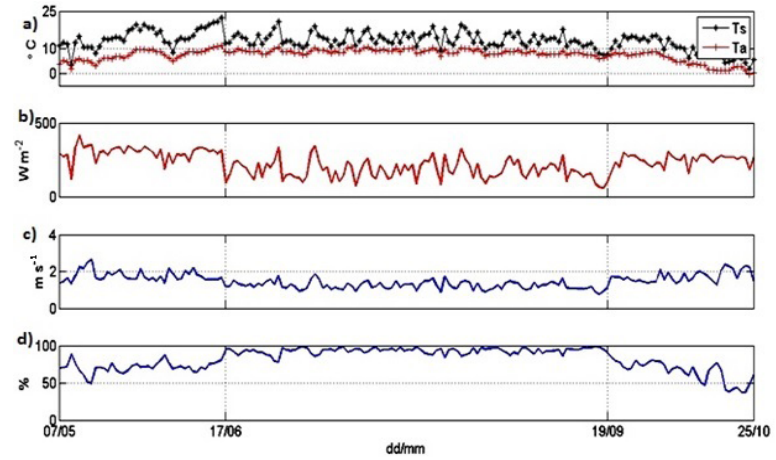

Figure 4: Hourly measurements of meteorological condition at the location of AWS on Lirung Glacier avegared over the entire period of record (a) Air (Ta) and surface (Ts) temperature $\left({ }^{\circ} \mathrm{C}\right)$, (b) Incoming shortwave radiation (W $\left.\mathrm{m}^{-2}\right)$, (c) Wind Speed $\left(\mathrm{m} \mathrm{s}^{-1}\right.$ ) and (d) Relative Humidity (\%).

\section{RESULTS AND DISCUSSION}

\subsection{Meteorological and Surface Condition}

We first looked at the variability and characteristics of air temperature above $2 \mathrm{~m}$ from the debris surface and surface temperature during three periods. Over the period of record, the daily maximum air temperature is $11.02{ }^{\circ} \mathrm{C}$ observed during the Period I and daily minimum air temperature is $-0.33{ }^{\circ} \mathrm{C}$ observed during the Period III.

Figure 4.a shows the hourly measurements of air and surface temperature over the entire measurement periods. It can be clearly seen that surface temperature is always higher than that of the air temperature and both shows similar pattern of variation. However, the surface temperature has much large diurnal oscillation than the air temperature.

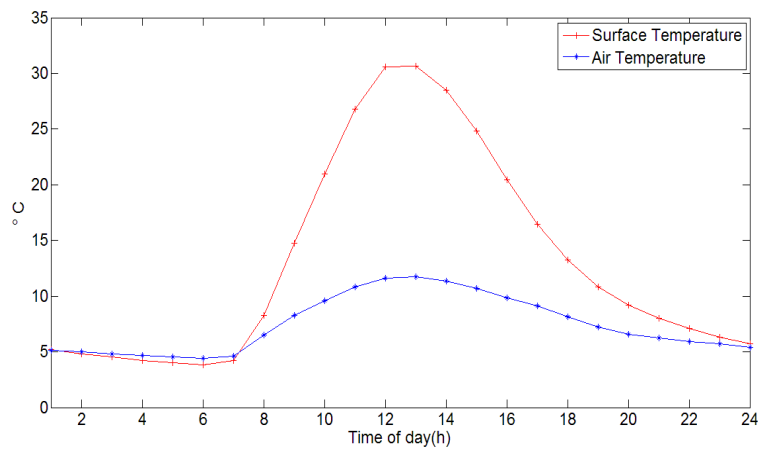

Figure 5: Mean daily fluctuations in air and surface temperature at AWS averaged over the entire period of record.

In this study, the day was divided into day (08:00 - 19:55) and night (20:00 - 07:55) to learn the behaviour of atmospheric variables during day and night. During the day, the surface temperature remains at higher than the air temperature but as the evening commence the surface temperature starts to decrease and eventually drops below the air temperature from 2:00 to 6:00 at AWS (Figure 5). This is due to the fact that the debris stores heat during the day time and release it slowly during the cold night time. So the surface temperature continues to decrease until the radiations from the sun starts to heat up the debris surface again at 08:00. It is also clear that the surface temperature undergoes higher variations over the day with a higher peak during the day and a lower temperature during night.

Analysis of incoming solar radiation data confirms that the mean daily maximum value of incoming solar radiation recorded to be $68.96 \%$ of the solar constant $\left(\mathrm{I}_{\mathrm{o}}=1367 \mathrm{Wm}^{-2}\right)$. The average incoming shortwave radiation at AWS over the entire measurement period is $221.06 \mathrm{Wm}^{-2}$. As expected, the incoming solar radiation decreases during monsoon but the air temperature increases (Figure 4.a and b) because of the cloud cover effect. The debris 

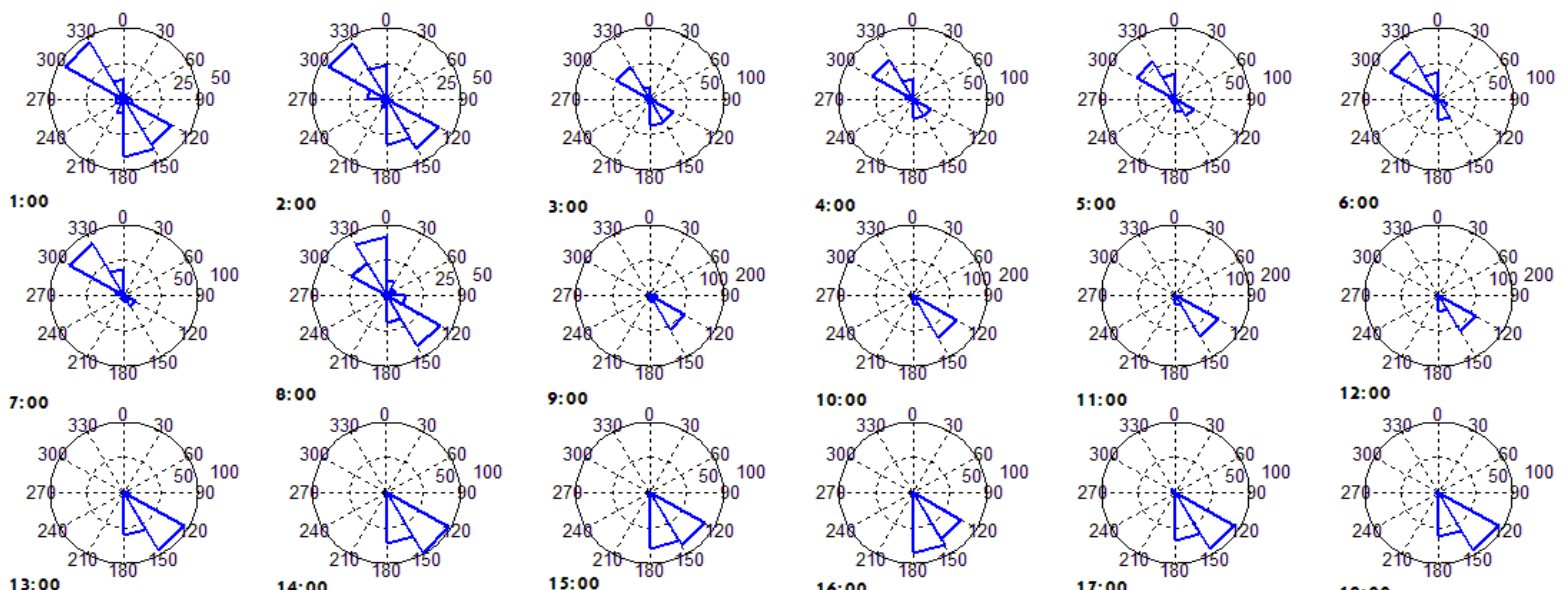

12:00
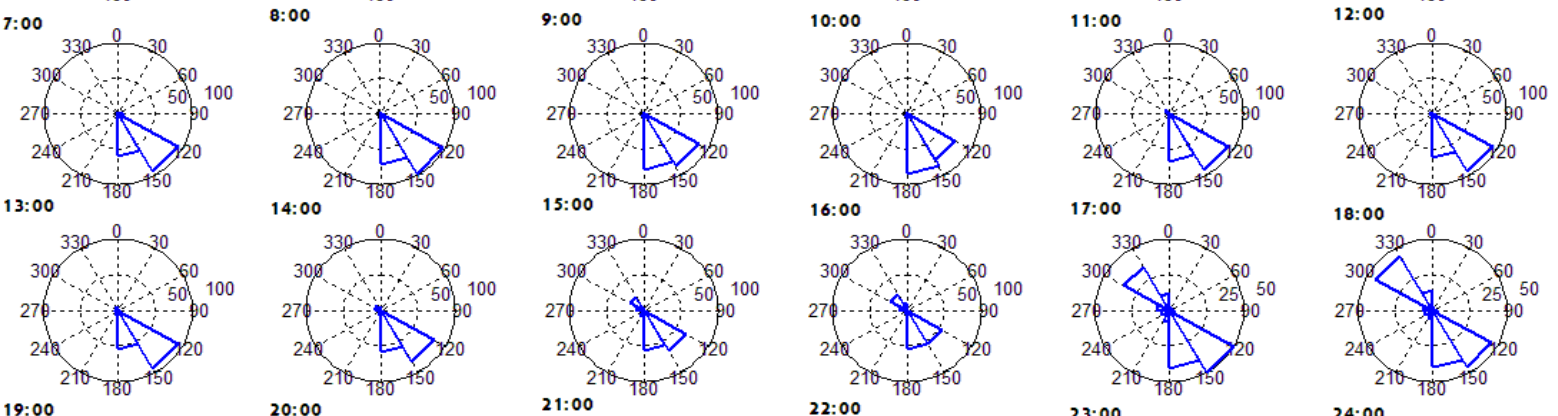

24:00

Figure 6: Distribution of the $\mathbf{2} \mathrm{m}$ hourly measurements of wind direction at AWS for the entire period of record. At this site, the down-glacier direction is $300-330^{\circ}$.

surface emits the longwave radiation (outgoing) to the atmosphere which is absorbed by the clouds formed during the monsoon which again tends to emit longwave radiation (incoming) part of which finds its way back to the glacier surface and hence increases the air temperature.

Analysis of wind speed shows that the maximum wind speed occurs around 12:00 - 14:00 during all seasons and all of them exhibit diurnal variations. During monsoon period, wind speed is lower compared to other dry periods (Figure 4.c). It may be due to the lower temperature deficit between the atmosphere and the glacier surface during this period.

Daily mean of relative humidity during the monsoon season is very high compared to other dry periods with its maximum value $98.40 \%$ due to the precipitation event during that period (Figure 4.d). Mean daily minima relative humidity over the period of measurement was found during Period III with its value $29.32 \%$.
Wind direction frequency at AWS is shown in Figure 6. The katabatic or glacier wind starts to develop and is felt only during night time (23:00 - 08:00) whereas valley wind dominates during the day time. This is due to increase in temperature gradient during the night time when the heat stored by the debris during day time is released back to the atmosphere and hence warming up the air temperature. During the day, the sun heats up air in contact with the debris surface rapidly. This causes it to rise, causing a warm, upslope wind (valley wind). At night, the process is reversed. Air at the top of mountain cools rapidly at night and fall downslope, causing a wind going in the other direction (Katabatic wind).

The katabatic wind during monsoon season is felt less (Figure 7). The predominant wind direction is equal to the up-glacier (Valley wind) direction for most of the day apart from the 23:00 - 08:00 time of day. During cloudy days (Period II case), the temperature deficit 
a)

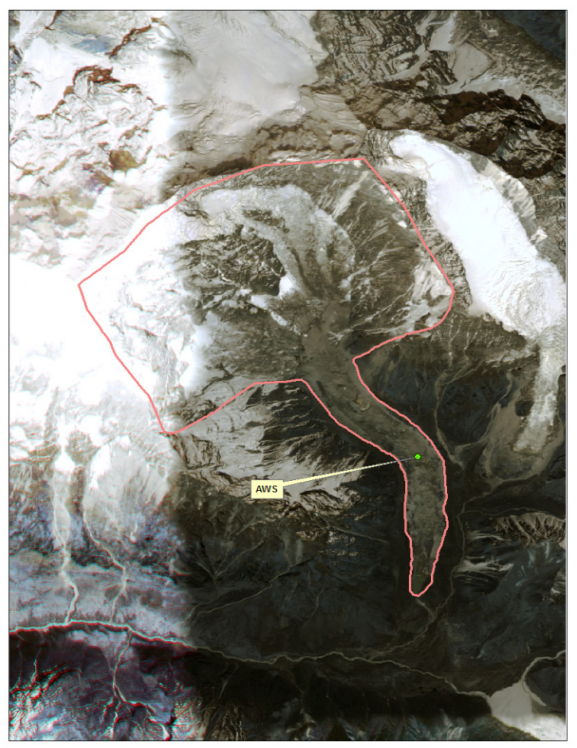

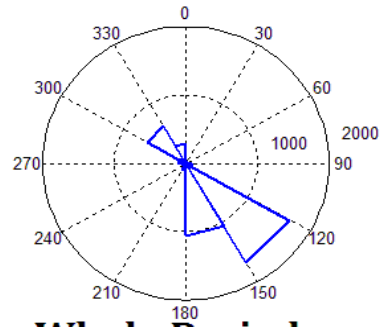

Whole Period

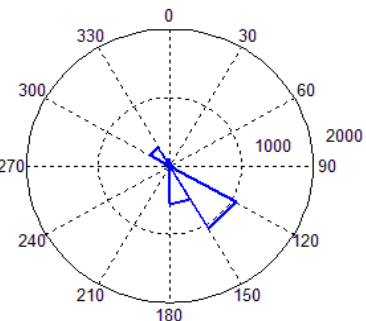

Period II

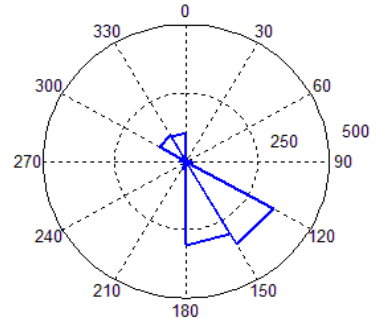

Period I

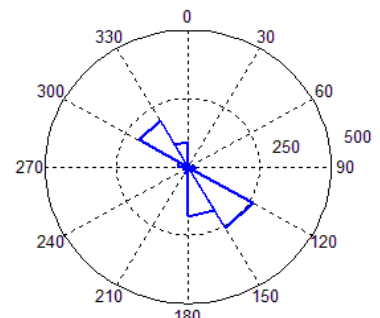

Period III

Figure 7(a) The glacier flow line and (b) Distribution of the $2 \mathrm{~m}$ hourly measurements of wind direction at AWS for the whole period and for different season.

is much lower between the top of mountain (where katabatic wind develops) and the glacier surface. So wind won't blow along the glacier flow line.

Katabatic force is created by the temperature contrast between the melting glacier surface and the ambient atmosphere, and a higher temperature contrast leads to stronger katabatic forces (Greuell et al., 1997). This is why katabatic winds are normally observed in

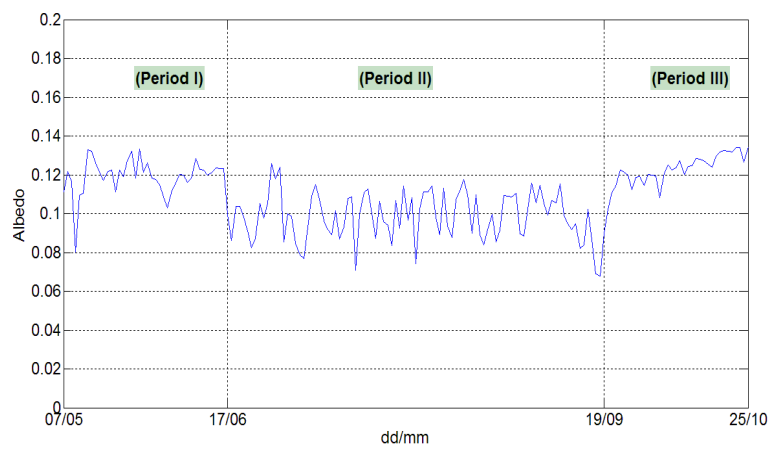

Figure 8: Daily albedo over the entire period of record. Daily albedo is computed as the mean of hourly albedo values when incoming shortwave radiation is above $120 \mathrm{~W} / \mathrm{m}^{2}$. the afternoon hours, following the hours of maximum air temperature (e.g. van den Broeke, 1997; Greuell and B“ohm, 1998; Greuell and Smeets, 2001; Klok et al., 2005).

Albedo is calculated as ratio of five minute reflected solar radiation and incoming solar radiation. For distributed modeling we need to parameterize the albedo as it is not constant in time and space (Figure 8). Albedo for Period I, II and III are calculated to be 0.11, 0.09 and 0.12 respectively.

The very high summer precipitation has an important effect on the albedo of debriscovered glaciers. Albedo decreases during the monsoon season. It is because precipitation during monsoon in the form of rain or snow (eventually melt to water due to heat conduction from the debris), when comes in contact with the debris surface, makes it darker in color. This phenomenon decreases the albedo of the debris thus absorbing much more solar radiation during the monsoon season. 


\subsection{Effects of debris thickness on of Ice ablation}

Surface temperature is measured only at AWS site, so we made use of the same surface temperature for all the debris thickness to calculate the melt. This assumption of homogenous surface temperature is acceptable since the melt rate calculated for certain debris thickness is found similar to the calculation done by Kayastha et al. (2000) for Khumbu Glacier and Rana et al. (1995) for Lirung Glacier.

Even though ablation stakes were installed at various debris thickness during 2012 field expedition, measurements were carried out at the interval of about one month for the whole measurement period. The instability and heterogeneity nature of the debris covered glacier makes this kind of measurement full of uncertainties. Over the course of the measurement periods, differential ablation, collapse of the ice faces, slumping and scree-fall down slopes gradually redistributes the debris over time resulting in local changes in debris thickness. So it is impossible to determine the actual melt amounts or debris thickness on each day. Hence, daily ablation at each site was estimated from the measured change in ice surface from the beginning to the end of the month, divided by the number of days of the measurement period.

Melt rate calculated from the energy balance equation is higher than the measured value (Figure 9) by $\sim 0.19 \mathrm{~cm} \mathrm{day}^{-1}$ for different debris thickness. Similar result was observed by Kayastha and others (2000) through continuous measurements over the course of the day, and found calculated values of melt rate beneath a $0.1 \mathrm{~m}$ thick debris layer up to double those measured in the field. This overestimation is reasonable because the assumption of an

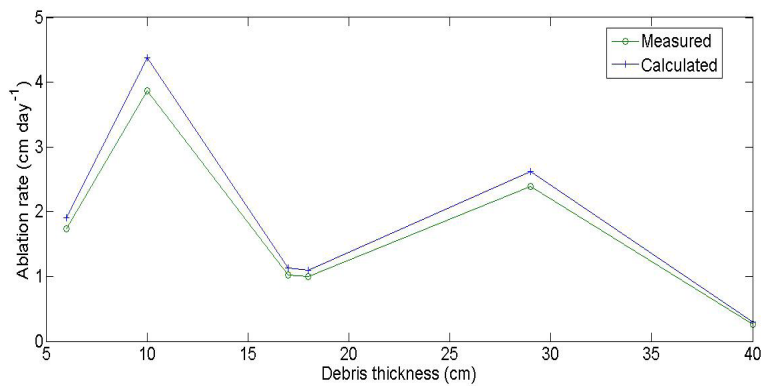

Figure 9: Comparison of measured and calculated daily ice ablation under different debris thickness. Daily ice ablation is calculated using the average thermal conductivity, which in turn is calculated from the measured daily ice ablation. Stake data for $\mathbf{2 0 1 2}$ was acquired by averaging the cumulative melt for 121 days (8 May to 5 September, 2012).

instantaneously linear temperature gradient does not account for the inversion of the temperature gradient that occurs at night, at least in the near subsurface, which results in heat flux towards the debris surface rather than towards the ice, such that initial energy inputs are used to raise the debris temperature rather than to melt ice (Nicholson and Benn, 2006). This can be explained by the fact that only variability comes from the surface temperature measured at the AWS site by setting the thermal conductivity to its mean value for each periods (I, II and III).

Adhikary et al. (2002) tested the sensitivity of aggregation of dust particles, assuming no aggregation of dust particles particularly for low dust concentration and found higher estimated ablation rate of snow compared with the actual observation. Similar assumption, i.e. the existence of aggregation of dust particles on a melting ice surface, has been taken into account in this study which explains the overestimated melt rate.

However there is no significant difference between these melt rate. This result indicate that the melt rates of debris-covered glaciers in the Himalayas could be calculated to a reasonable degree of accuracy using only variability in 

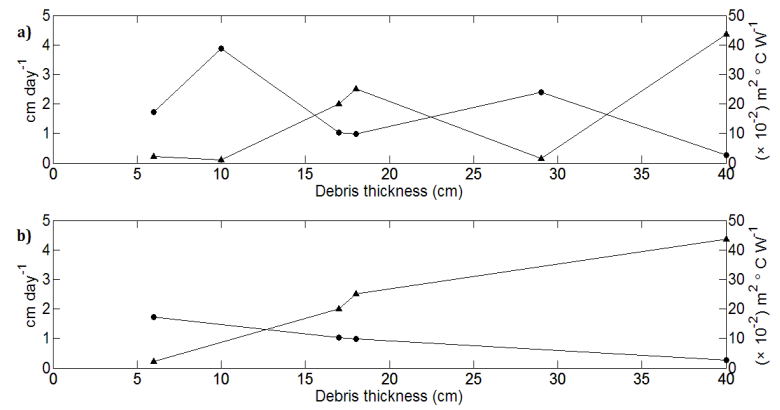

Figure 10: Variation of measured mean daily ice ablation (cm day ${ }^{-1}$ ) (line with solid dots) and calculated thermal resistance $\left(\mathrm{m}^{2}{ }^{\circ} \mathrm{C} \mathrm{W}^{-1}\right)$ (line with solid triangles) with respect to debris thickness. (a) including the data for $10 \mathrm{~cm}$ and $29 \mathrm{~cm}$ debris thickness and (b) excluding the data for respective debris thickness.

surface temperature when thermal conductivity is known for the specific site. Some of the measurements from the ablation stakes does not make any sense, so reading from these stakes are discarded.

More melt even at thick debris thickness (10 and $29 \mathrm{~cm}$ ) can be explained by the location of the stakes (stake 5 and 2 respectively) on the glacier (Figure 3 and 10). These stakes were installed near the glacier terminus which is active due to the ice exposure and melting of several ice cliffs around them which result into wash down of the debris during monsoon period decreasing its thickness and hence more melt. Upon excluding the melt obtain from debris thickness of $10 \mathrm{~cm}$ and $29 \mathrm{~cm}$, the curve shown in Figure 10.b corresponds with the curve obtain by Kayastha et al. (2000) for Khumbu Glacier.

The energy balance method is used to demonstrate the importance of each energy fluxes responsible for ice melt underneath the debris layer. For this the energy balance components are calculated only for AWS site since continuous surface temperature is available only for this site. The variation of energy balance components are shown in Figure 11. Figure 11 shows the main energy

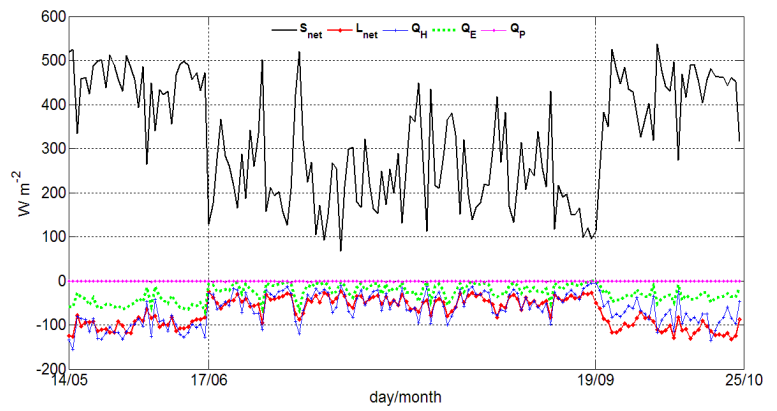

Figure 11: Variations of calculated daily energy balance components on AWS site.

source is the net radiation, which contributes near $100 \%$ of total energy available for melting of ice under debris cover. Due to the higher surface temperature than the air temperature and evaporation from the wet debris, all energy balance components are negative except shortwave radiation.
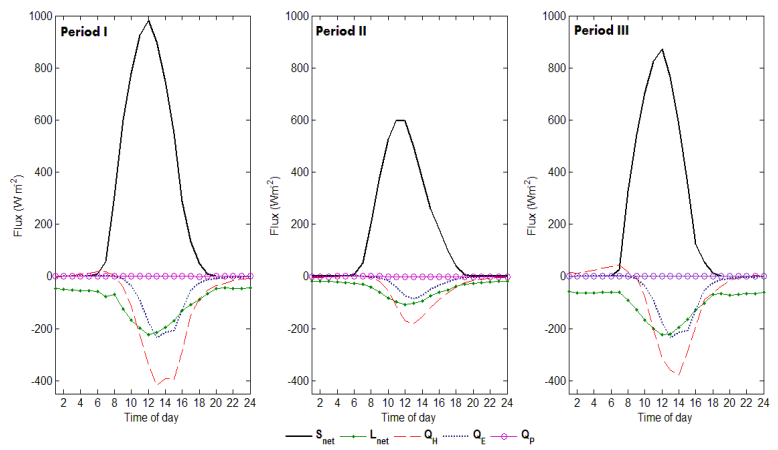

Figure 12: Mean daily cycles of calculated surface heat fluxes for Period I, II and III on AWS site.

The significance of each surface heat fluxes during dry and wet period is considered in Figure 12 which shows the mean daily cycles of surface heat fluxes for all three measurement periods. It is clear from this figure that the net radiation is the only dominant source of melt during the day time and other fluxes act as a sink but during night there is a little contribution of sensible heat flux to the melt process during two dry periods (about $1.2 \%$ in period I and $4.1 \%$ in period III) whereas the turbulent flux like the latent heat, heat due to precipitation and net longwave radiation remains negative throughout 
the time of day. This can be explained with the fact previously mentioned about the heat storage and release phenomenon in the debris during the day and night time respectively.

\section{CONCLUSION}

The simple model used in this paper develops a method of estimating ice ablation under a supraglacial debris cover with high degree of accuracy when the variability comes only from surface temperature data. The model assume daily mean temperature gradients to be linear and there is negligible net change in heat storage on diurnal timescales. Despite numerous simplification, taking the average value of thermal resistance $(R)$ into account, the proposed method gave the consistent value of melt. However, the effect of the debris layer on ablation of glacier ice should be studied in association with meteorological variables. Solar radiation is the only dominant heat flux which contributes to melting of ice under the debris cover with a little contribution of sensible heat flux in dawn because of the heat storage phenomenon of the debris. Nevertheless, further efforts must be made through a series of studies to improve and justify the model's ability to predict ablation under thick debris cover over a longer period with cautious and detail measurements of meteorological variable (especially for sensible and latent heat flux) in the monsoon fed glaciers. The major advantage of this model is that it requires only a few data to model ablation rates for a debris-covered glacier. This could be particularly important for studies carried out in regions where there is limited availability of observed data. The main challenge, particularly in glacial modeling at a regional scale, is in acquiring information on the extent, thickness and thermal properties of supraglacial debris covers, which remains future research work.

\section{ACKOWLEDGEMENTS}

We would like to express our sincere gratitude to Cryosphere Monitoring Project's executor the International Centre for Integrated Mountain Development (ICIMOD) and financial supporter the Norwegian Ministry of Foreign Affairs, Norway. We are also extremely thankful to the project partners for their help in carrying out this study, including the Himalayan Cryosphere, Climate and Disaster Research Center, Kathmandu University; Central Department of Hydrology and Meteorology, Tribhuvan University; Department of Hydrology and Meteorology, Government of Nepal; and Water and Energy Commission Secretariat, Government of Nepal. We are also thankful to the ETH, Zurich, Switzerland for instrumentation during the field campaign.

\section{REFERENCES}

Adhikary, S., Seko, K., Nakawo, M., Ageta, Y.,Miyazaki, N., 1997. Effect of surface dust on snow melt. Bulletin of Glacier Research 15, 85-92.

Adhikary, S., Nakawo, M., Seko, K., Shakya, B., 2000.Dust influence on the melting process of glacier ice: experimental results from Lirung Glacier, Nepal Himalayas. IAHS Publ. no. 264, 43-52.

Adhikary, S., Yamaguchi, Y. \& Ogawa, K., 2002. Estimation of snow ablation under a dust layer covering a wide range of albedo. Hydrological Processes, 16, 2853-2865. 
Asahi, K., 1998. Recent glacier fluctuation and their factors of eastern Nepal Himalaya (in Japanese). 151p. Master thesis, Tokyo Metropolitan University.

Benn, D. I., Kirkbride, M. P., Owen, L. A. and Brazier, V., 2004. Glaciated valley landsystems. In Evans, D.J.A., ed. Glacial landsystems. London, Edward Arnold, 372-406.

Bondarev, L. G., 1961. Evolution of some Tien Shan glaciers during the last quarter of the century. International Association of Scientific Hydrology Publication 54 (General Assembly of Helsinki 1960, Snow and Ice): 412-419.

Bozhinskiy, A.N., Krass, M.S. and Popovnin, V.V., 1986. Role of debris cover in the thermal physics of glaciers. J. Glaciol., 32(111), 255-266.

Brock, B., Rivera, A., Casassa, G., Bown, F. and Acuña, C., 2007. The surface energy balance of an active icecovered volcano: Volcán Villarrica, southern Chile, Ann. Glaciol., 45, 104-114.

Brock, B. W., Mihalcea, C., Kirkbride, M. P., Diolaiuti, G., Cutler, M. E. J. and Smiraglia, C., 2010. Meteorology and surface energy fluxes in the 2005-2007 ablation seasons at the Miage debriscovered glacier, Mont Blanc Massif, Italian Alps. J. Geophys. Res., 115(D9), D09106.

Dilley, A. C. and O'Brien, D. M., 1998. Estimating downward clear sky longwave irradiance at the surface from screen temperature and precipitable water. Q. J. J. Meteorol. Soc. 124:1391-401.
Fujii, Y., 1977. Experiment on glacier ablation under a layer of debris cover, Seppyo, J. Jpn. Soc. Snow Ice, 39, 20-21.

Glazyrin, G. E., 1975. The formation of ablation moraines as a function of the climatological environment. International Association of Hydrological Sciences Publication 104 (General Assembly of Moscow 1971, Snow and Ice): 106-110.

Greuell, W., Knap, W. H. and Smeets, P. C., 1997. Elevational changes in meteorological variables along a mid-latitude glacier during summer. Journal of Geophysical Research 102(D22): 25941-25954.

Greuell, W. and B“ohm, R., 1998. 2m temperatures along melting midlatitude glaciers, and implications for the sensitivity of the mass balance to variations in temperature. Journal of Glaciology 44(146): 9-20.

Greuell, W. and Smeets, P., 2001. Variations with elevation in the surface energy balance on the Pasterze (Austria). Journal of Geophysical Research 106(D23): 31717-31727.

Hagg, W., Mayer, C., Lambrecht, A. and Helm, A., 2008. Subdebris melt rates on southern Inylchek Glacier, central Tian Shan, Geogr. Ann., Ser. A., 90, 55-63.

Hay, J. E. and Fitzharris, B. B., 1988. A comparison of the energy balance and bulk-aerodynamic approaches for estimating glacier melt. J. Glaciol., 34(117), 145-153.

Inoue, J., 1977. Mass budget of Khumbu glacier. Journal of the Japanese Society of Snow and Ice 39 (Special Issue): 15-19. 
Kayastha, R.B., Y. Takeuchi, M. Nakawo and Y. Ageta. 2000. Practical prediction of ice melting beneath various thickness of debris cover on Khumbu Glacier, Nepal using a positive degree-day factor. $I A H S$ Publ. 264, 71-81.

Kite, G. W. and Reid, I. A., 1977. Volumetric change of the Athabasca Glacier over the last 100 years. Journal of Hydrology 32(3-4): 279-294.

Klok, E. J., Nolan, M., van de Broeke, M. R., 2005. Analysis of meteorological data and the surface energy balance on McCall Glacier, Alaska, USA. Journal of Glaciology 51(174): 451-461.

Loomis, S. R., 1970. Morphology and ablation processes on glacier ice. Proceedings of the Association of American, Geographers 2: 88-92.

Mihalcea, C., Mayer, C., Diolaiuti, G., Lambrecht, A., Smiraglia, C. and Tartari, G., 2006. Ice ablation and meteorological conditions on the debris covered area of Baltoro Glacier (Karakoram, Pakistan), Ann. Glaciol., 43, 292-300.

Mihalcea, C. and 7 others., 2008. Using ASTER satellite and ground-based surface temperature measurements to derive supraglacial debris cover and thickness patterns on Miage Glacier (Mont Blanc Massif, Italy). Cold Reg. Sci. Technol., 52(3), 341-354.

Moribayashi, S. and Higuchi, K., 1972. Yusetsu no jinko yokusei ni kansuru kisoteki kenkyu [On experiments on reducing the melting of snow]. Journal of the Japanese Society of Snow and Ice 34(4): 165-172.
Nakawo, M., 1979. Supraglacial debris of G2 glacier in Hidden Valley, Mukut Himal, Nepal. Journal of Glaciology 22(87): 273-283.

Nakawo, M., and Young, G.J., 1981. Field experiments to determine the effect of a debris layer on ablation of glacier ice. Annals of Glaciology 2, 85-91.

Nakawo, M. and Young, G. J., 1982. Estimate of glacier ablation under a debris layer from surface temperature and meteorological variables. Journal of Glaciology, 28, 29-34.

Nakawo, M. and Rana, B., 1999. Estimate of ablation rate of glacier ice under a supraglacial debris layer. Geografiska. Annaler., 81 A (4): 695-701.

Naruse, R., Oura, H. and Kojima, K., 1970. Field studies on snow melt due to sensible heat transfer from the atmosphere. Teon Kagaku: Low temperature Science, series A (28), 191-202.

Nicholson, L., and Benn, D. I., 2006. Calculating ice melt beneath a debris layer using meteorological data, J. Glaciol., 52, 463-470.

Østrem, G., 1959. Ice melting under a thin layer of moraine, and the existence of ice cores in moraine ridges. Geogr. Ann., 41(4), 228-230.

Rana, B., Nakawo, M., Ageta, Y. and Seko, K., 1995. Glacier Ablation under Debris Cover: Field observations on Lirung Glacier, Nepal Himalayas. In: Proc. International Conference on Ecohydrology of High Mountain Areas (24-28 March, Kathmandu), 393-403. International Centre for Integrated 
Mountain Development, Kathmandu, Nepal.

Reid, T. D. and Brock, B. W., 2010. An energybalance model for debris-covered glaciers including heat conduction through the debris layer. Journal of Glaciology , 56, 903-916.

Singh, P., Arora, M. and Goel, N. K., 2006. Effect of climate change on runoff of a glacierized Himalayan basin, Hydrol. Process., 20, 1979- 1992.

Unsworth, M. H. and Monteith, J. L., 1975. Long-wave radiation at the ground I. Angular distribution of incoming radiation. Q.J.R. Meteorol. Soc., 101: 13-24.
Van den Broeke, M. R., 1997. Structure and diurnal variation of the atmospheric boundary layer over a mid-latitude glacier in summer. Boundary-Layer Meteorology 83(2): 183-205.

Whalley, W. B., 1979. The relationship of glacier ice and rock glacier at Grubengletscher, Kanton Wallis, Switzerland. Geografiska Annaler 61A(1-2): 49-61.

Wijngaarden, H van., 1961. Investigations concerning the transport of heat through a solid sheet of ice in periods of frost and thaw. International Association of Scientific Hydrology Publication 54 (General Assembly of Helsinki 1960, Snow and Ice): 40-55. 